\title{
The Prevalence of Paranasal Sinus Anatomic Variations on Cone Beam Computed Tomography Scan Images of Turkish Population
}

\author{
M. Oguz Borahan (D), Gamze Ulay (D), Ayse Nur Yildiz Sadikoglu (D), Filiz Namdar Pekiner (D) \\ Marmara University, School of Dentistry, Department of Oral Diagnosis and Radiology, İstanbul, Turkey \\ Correspondence Author: M. Oguz Borahan \\ E-mail: oguzborahan@hotmail.com \\ Received: $17.01 .2018 \quad$ Accepted: 21.02.2018
}

\begin{abstract}
Objectives: The paranasal sinuses include anatomic structures at the maxillofacial region that matters great importance for the surgeons working in the maxillofacial area. The imaging of anatomic variations of the paranasal sinuses is fundamental to evaluate the predisposing factors for the pathologic changes of paranasal sinuses. The aim of this study is to investigate the prevalence of anatomic variations of the paranasal sinuses by retrospective assessment of cone beam computed tomography (CBCT) images.

Methods: The paranasal sinus CBCT images of 300 adult patients who were referred to Marmara University, Faculty of Dentistry, Department of Oral Diagnosis and Radiology were evaluated retrospectively. The paranasal sinus variations and their prevalence were recorded.

Results: The prevalence of concha bullosa superior was $7,7 \%$, and concha bullosa media was $54,7 \%$. The prevalence of infraorbital ethmoid cell was $15,3 \%$, agger nasi cell was $52,7 \%$ and onodi cell was $52.7 \%$. There was no significant differences prevalence of this anatomic variations between males and females or between different age groups.

Conclusions: $\mathrm{CBCT}$ is a convenient radiographic examination to evaluate the paranasal sinus anatomic variations. Dental surgeons must be aware of such anatomic variations of the paranasal sinuses.

Keywords: $\mathrm{CBCT}$, paranasal sinuses, anatomic variations
\end{abstract}

\section{INTRODUCTION}

The sinonasal cavities, presented by the ostiomeatal complex and paranasal sinuses, are the vital parts of the upper respiratory tract (1). Ostiomeatal complex is a functional unit which is a limited anatomical region consisting of: middle turbinate, uncinate process, bulla ethmoidalis as bony structures; frontal recess, ethmoidal infundibulum, middle meatus as air spaces; and anterior ethmoidal, maxillary and frontal sinuses as ostia. Furthermore, the paranasal sinuses include anatomic structures at the maxillofacial region that matters great importance for the surgeons working in the maxillofacial area (2).

Surgical approaches on the paranasal sinuses are among the most frequent operations in otorhinolaryngology and functional endoscopic sinus surgery (FESS) has become one of the commonest surgical procedures performed by otolaryngologists (3-6). The keystone of FESS is the capacity to treat even comparatively minor changes exactly, which obstruct mucociliary clearance of the frontal, ethmoid and maxillary sinuses in osteomeatal complex (6).

All the surgical interventions in this area require comprehensive information of anatomy and potential anatomical variations. These variations with an impact on surgical reliability occur frequently and is essential particularly to investigate as a piece of preoperative evaluation (7). During FESS, the thorough elimination of these variations is necessary to ensure adequate opening of the sinuses and thus provide for physiological drainage and ventilation. The incomplete removal of variations in the sinuses is one of the most prevalent causes of FESS failure (7).

Anatomic variations, such as, concha bullosa, ethmoidal bulla hypertrophic, agger nasi cell and infraorbital ethmoid cell are common and evaluated in routine computed tomography (CT) images (8). CT is the gold standard modality for imaging the complex and variable anatomy of the paranasal sinuses for pre-operative recognition and especially in the assessment of causes for surgical failure $(9,10)$. Multiplanar CT imaging achieves and greatly improves the understanding of the paranasal sinuses by standard axial or coronal CT images of the sinus with addition of sagittal reconstructions $(11,12)$.

Cone beam computed tomography (CBCT), a more recent technological development, provides detailed anatomical information of mineralized maxillofacial tissues as threedimensional images with minimal distortion. CBCT has been recommended as a perfect, relatively inexpensive instrument 
for the assessment of these anatomical structures with lightly more radiation according to the panoramic radiograph and much fewer according to CT scan (13-15).

The aim of this retrospective study is to investigate the prevalence of anatomic variations of the paranasal sinus region using $\mathrm{CBCT}$ in a group of Turkish patients.

\section{METHODS}

\subsection{Patient Data}

Subjects for this retrospective study consist of all 300 patients who visited Marmara University, Faculty of Dentistry, Department of Oral Diagnosis and Radiology() and CBCT images of these patients between 2016-2017 were retrieved from the PACS system. CBCT imaging was performed with Planmeca Promax 3D Mid (Planmeca Oy, Helsinki, Finland) and assessment of CBCT was performed directly on monitor screen (Monitor 23 inch Acer 1920x1080 pixel HP Reconstruction PC). The purpose of CBCT scans were for impacted third molar surgery, orthodontic purposes, dental implant treatment and Le Fort I osteotomy. Patients with systemic diseases influencing growth and development, history of trauma and/or surgery involving the maxillofacial region, developmental anomalies/pathologies affecting the maxillofacial region, sinusitis, sinonasal polyposis, sinus malignancy, fibroosseous lesions, and previous sinus surgery were excluded from the study. The written informed consent was signed by the patients before CBCT scans. The study was carried out according to the recommendations of the Helsinki declaration and the study protocol was approved by the Local Committee of Research and Ethics of Marmara University, Faculty of Medicine (Protocol No: 09.2017.009).

\subsection{Image interpretation}

Two oral and maxillofacial radiologist (GU, ANYS) evaluated and interpreted anatomic variations; concha bullosa, agger nasi cell, infraorbital ethmoid cell and onodi cell. Before starting the radiographic examination in the study, the examiners were calibrated to recognize and agree on paranasal sinus anatomy and variations. For such purpose, a series of 50 CBCT were used (not included in this study) were examined. As part of the calibration phase, the examiners were given also explanations about radiographic and CBCT imaging.

The variations were identified on the left and right side separately. The recognition of these variations were made according to literature that were already described by means of multi-planar CT images (3).

Agger nasi cells (ANCs); are the most anterior ethmoid single cell, swelling along lateral nasal wall anterior to middle turbinate vertical attachment and are best viewed on coronal and sagittal planes. In the coronal plane, their position is inferior to the frontal sinus and anterior to the middle turbinate (16) (Figure 1).

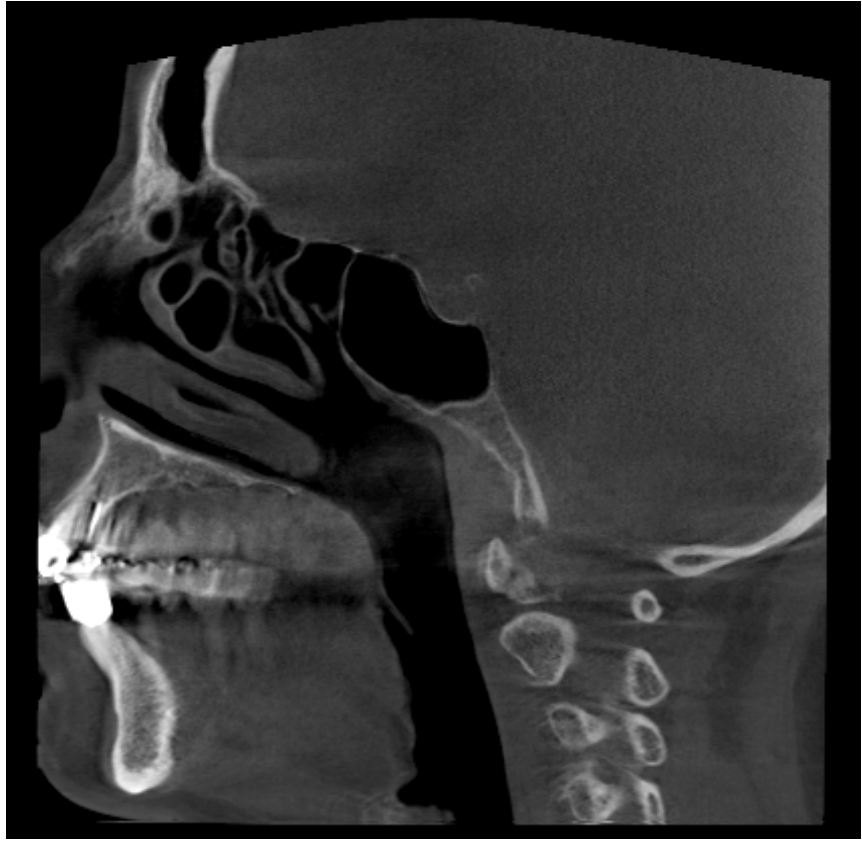

Figure 1. Sagittal view of agger nasi cell

Concha bullosa is described as occurrence of an air space within the lamina recurvata, free hanging portion of the turbinate. This space can be very small or can reach a pretty big size (Figure 2). Concha bullosa may be seen on the middle turbinate and, less often, on the inferior and superior ones. Concha bullosa can be identified in coronal CT scan images plainly $(17,18)$.

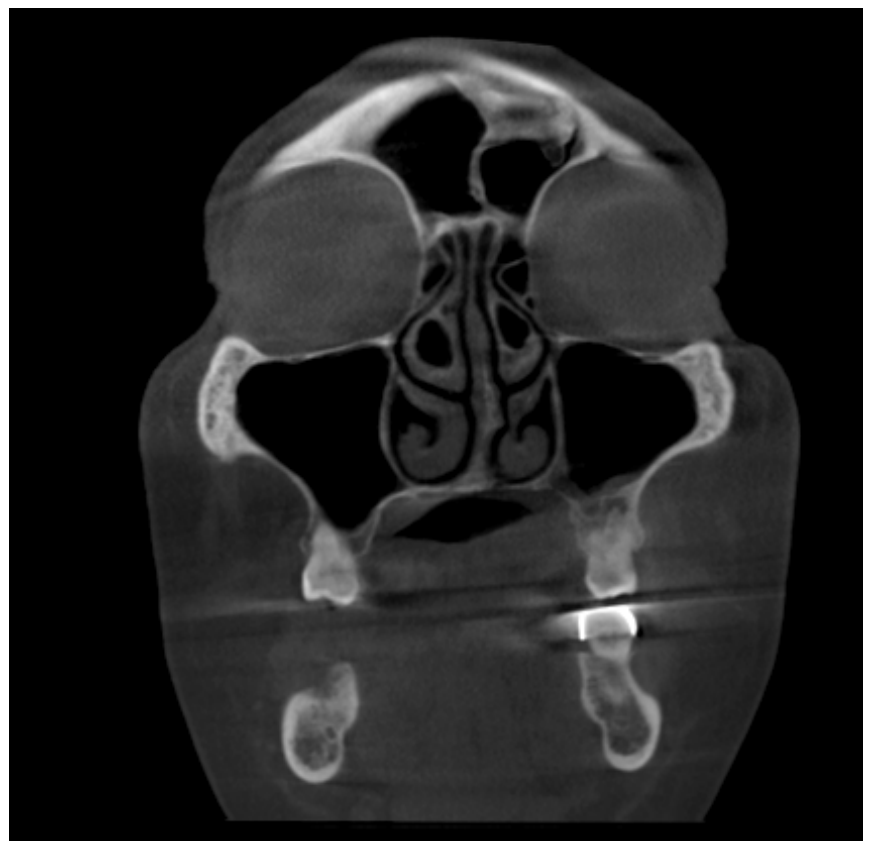

Figure 2. Bilateral concha bullosa medium on coronal section

Infraorbital ethmoid cells are described as air cells situated below the ethmoid bulla along the roof of the maxillary sinus and the most inferior portion of the lamina papyracea, including air cells located within the ethmoid infundibulum 
(Figure 3) (19). The existence of infraorbital ethmoid cells has been associated with various symptoms and diseases, including sinusitis, headaches, and mucoceles (19-21).

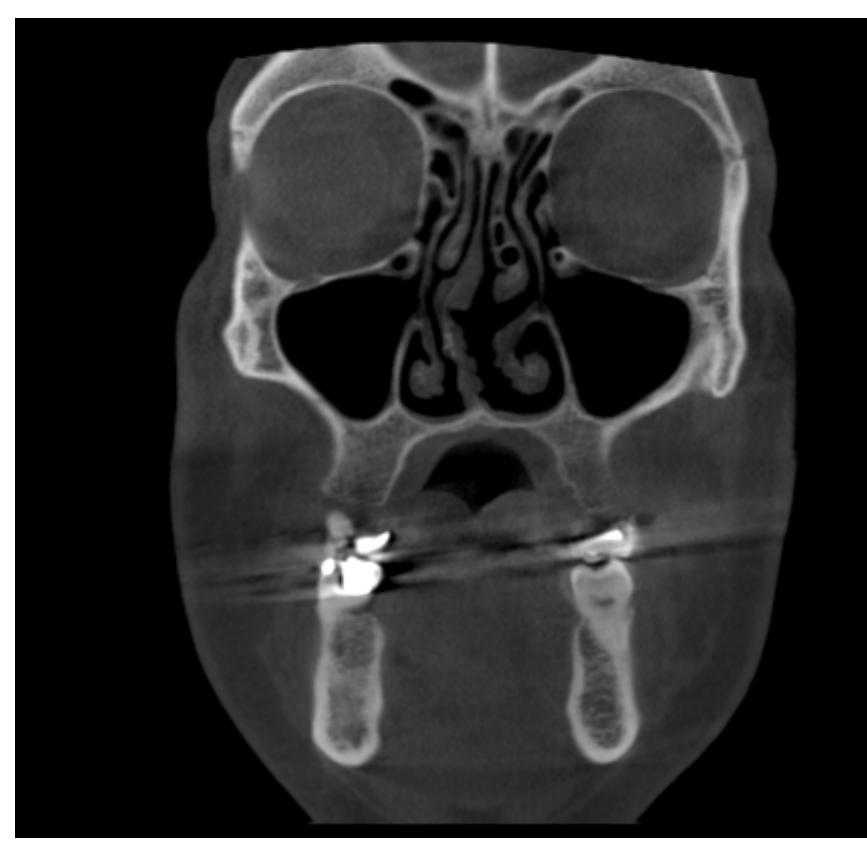

Figure 3 . Coronal view of bilateral infraorbital ethmoid cell

The Onodi cell is a posterior ethmoid cell which pneumatized far laterally and to some degree superiorly to the sphenoid sinus and is closely associated with the optic nerve (Figure 4) (18). Chmielik and Chmielik (22) suggested all multiplanar reconstructions of the $\mathrm{CT}$ examinations should be analyzed in the preoperative sinus CT evaluation, to identify and characterize Onodi cells, recommending axial and sagittal planes preferable in their study.

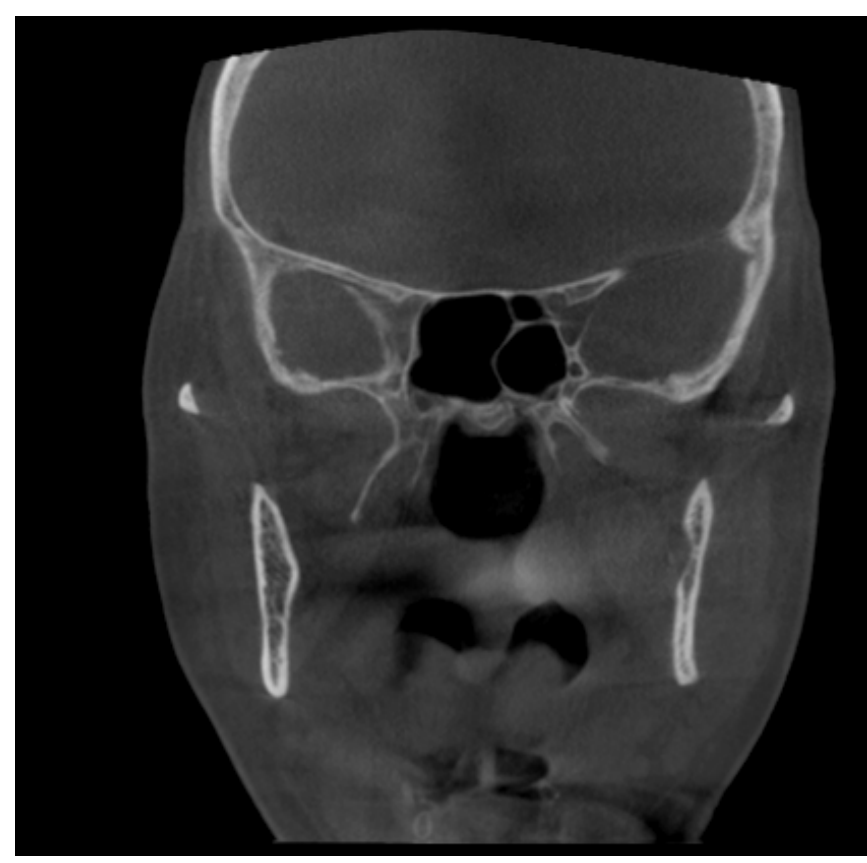

Figure 4. Onodi cell on coronal CBCT section

\subsection{Statistical analysis}

The data were analysed with IBM Statistical Package for Social Sciences (SPSS) for Windows 15.0 (SPSS Inc, Chicago, IL). Descriptive statistical methods (mean, SD, and frequency) were used for evaluation of the data. Chi-square test was used to compare qualitative data. Values of $p<0.05$ were interpreted as significant.

\section{RESULTS}

A total of 300 patients met the inclusion criteria aged between 18 and 85 with 134 (44,7\%) male and 166 (55,3\%) female. The mean age is $47.13 \pm 14.75$ years. Of the 300 patients, 21 of the patients (7\%) were between $18-24$ years, $46(15,3 \%)$ between the ages of $25-34,68(22,7 \%)$ between the ages of $35-44,62(20,7 \%)$ are between the ages of $45-54$ and $103(34,3 \%)$ are above the age of 55 (Table 1).

Table 1. Distribution of age and gender

\begin{tabular}{|l|l|l|l|}
\hline Age & \multicolumn{2}{|c|}{$\mathbf{n}$} & $\%$ \\
\hline & $18-24$ & 21 & 7,0 \\
\hline & $25-34$ & 46 & 15,3 \\
\hline & $35-44$ & 68 & 22,7 \\
\hline & $45-54$ & 62 & 20,7 \\
\hline Gender & Above 55 & 103 & 34,3 \\
\hline & Male & 134 & 44,7 \\
\hline & Female & 166 & 55,3 \\
\hline
\end{tabular}

While concha bullosa superior was not seen in $92,3 \%$ of the cases, bilateral, right and left concha bullosa superior was present in 2\%,2,3\% and 3,3 respectively. Concha bullosa media was absent in $45,3 \%$. They were present bilaterally in $22,3 \%$, unilaterally right side in $14.7 \%$ and and unilaterally left side in $17.7 \%$. Concha bullosa inferior was not observed in any cases (Table 2).

Table 2. Paranasal Sinus Anatomical Variations

\begin{tabular}{|l|l|l|l|}
\hline Concha Bullosa Superior & Absent & 277 & 92,3 \\
\hline & Bilateral & 6 & 2,0 \\
\hline & Right & 7 & 2,3 \\
\hline & Left & 10 & 3,3 \\
\hline Concha Bullosa Media & Absent & 136 & 45,3 \\
\hline & Bilateral & 67 & 22,3 \\
\hline & Right & 44 & 14,7 \\
\hline & Left & 53 & 17,7 \\
\hline Concha Bullosa Inferior & Absent & 300 & 100,0 \\
\hline Infraorbital ethmoid cells & Absent & 254 & 84,7 \\
\hline & Bilateral & 15 & 5,0 \\
\hline & Right & 14 & 4,7 \\
\hline & Left & 17 & 5,7 \\
\hline Agger Nasi Cell & Absent & 142 & 47,3 \\
\hline & Bilateral & 108 & 36,0 \\
\hline & Right & 20 & 6,7 \\
\hline & Left & 30 & 10,0 \\
\hline Onodi Cells & Absent & 142 & 47,3 \\
\hline & Present & 158 & 52,7 \\
\hline
\end{tabular}


In $84,7 \%$ of the cases, no infraorbital ethmoid cells were observed, $5 \%$ of the cases were bilateral, $4,7 \%$ were on the right side and $5,7 \%$ were on the left side. In $47,3 \%$ of the cases, agger nasi cells were absent; in $36 \%$ bilateral, in $6,7 \%$ on the right side and in $10 \%$ on the left side agger nasi cell were present. In $47,3 \%$ of the cases, no onodi cells were observed while in $52,7 \%$ of the cases onodi cells were present (Table 2) .
There was no statistically significant difference between the incidence rates of concha bullosa superior and concha bullosa media, infraorbital ethmoid cells, agger nasi, onodi cells according to age groups ( $p>0.05$ ) (Table 3 ).

There was no statistically significant difference between the incidence rates of concha bullosa superior and concha bullosa media, infraorbital ethmoid cells, agger nasi, onodi cells cells according to gender ( $p>0.05$ ) (Table 4).

Table 3. Assessment of paranasal sinus anatomic variations according to age groups

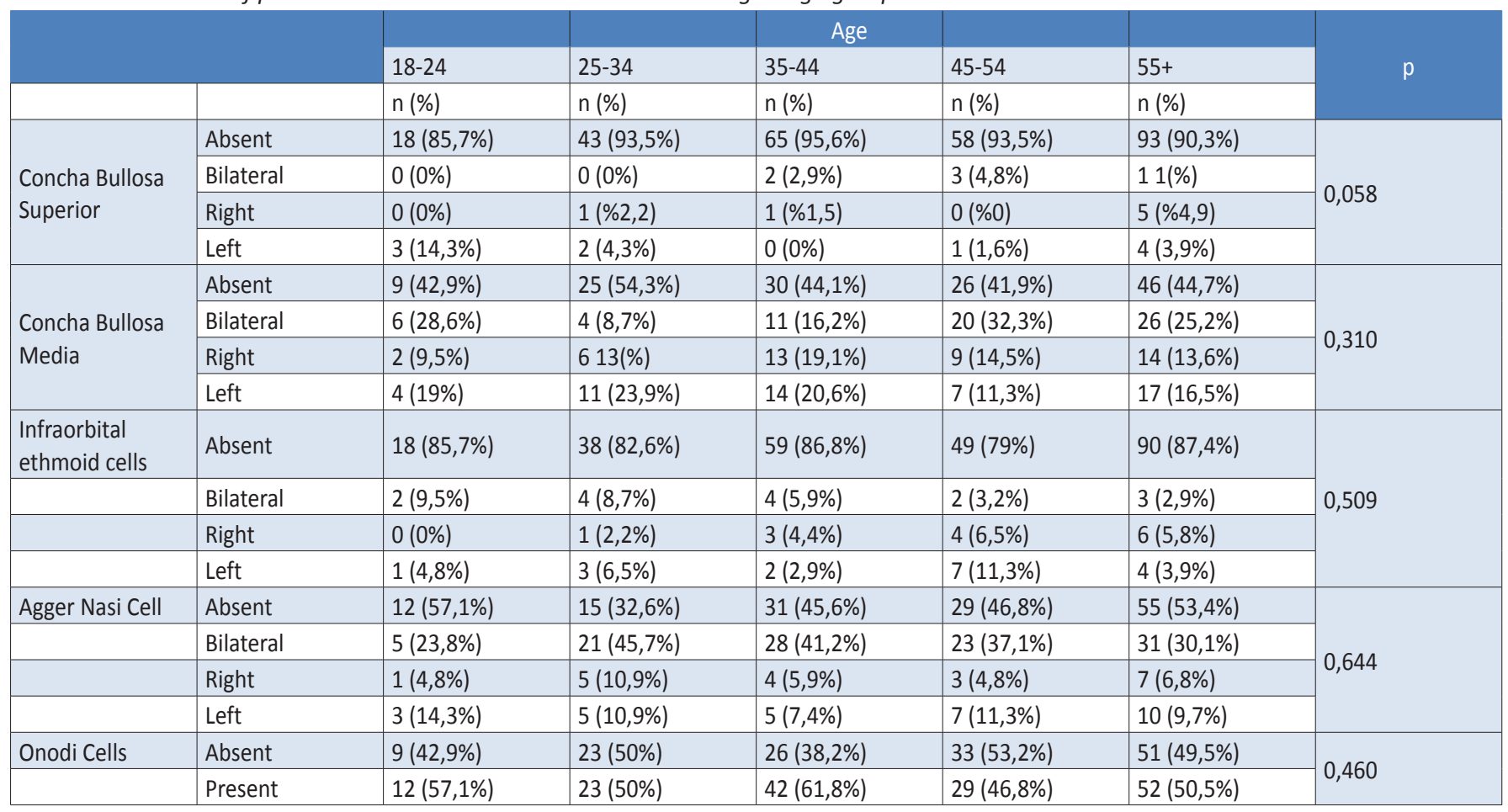

Table 4. Assessment of paranasal sinus anatomic variations according to gender

\begin{tabular}{|c|c|c|c|c|}
\hline & & \multicolumn{2}{|c|}{ Gender } & \multirow[t]{3}{*}{$\mathrm{p}$} \\
\hline & & Male & Female & \\
\hline & & $\mathrm{n}(\%)$ & $n(\%)$ & \\
\hline \multirow[t]{4}{*}{ Concha Bullosa Superior } & Absent & $120(89,6 \%)$ & $157(94,6 \%)$ & \multirow[t]{4}{*}{0,428} \\
\hline & Bilateral & $4(3 \%)$ & $2(1,2 \%)$ & \\
\hline & Right & $4(3 \%)$ & $3(1,8 \%)$ & \\
\hline & Left & $6(4,5 \%)$ & $4(2,4 \%)$ & \\
\hline \multirow[t]{4}{*}{ Concha Bullosa Media } & Absent & $67(50 \%)$ & $69(41,6 \%)$ & \multirow[t]{4}{*}{0,298} \\
\hline & Bilateral & $29(21,6 \%)$ & $38(22,9 \%)$ & \\
\hline & Right & $20(14,9 \%)$ & $24(14,5 \%)$ & \\
\hline & Left & $18(13,4 \%)$ & $35(21,1 \%)$ & \\
\hline \multirow[t]{4}{*}{ Infraorbital ethmoid cells } & Absent & $109(81,3 \%)$ & $145(87,3 \%)$ & \multirow[t]{4}{*}{0,498} \\
\hline & Bilateral & $9(6,7 \%)$ & $6(3,6 \%)$ & \\
\hline & Right & $7(5,2 \%)$ & $7(4,2 \%)$ & \\
\hline & Left & $9(6,7 \%)$ & $8(4,8 \%)$ & \\
\hline \multirow[t]{4}{*}{ Agger Nasi Cell } & Absent & $68(50,7 \%)$ & $74(44,6 \%)$ & \multirow[t]{4}{*}{0,180} \\
\hline & Bilateral & $40(29,9 \%)$ & $68(41 \%)$ & \\
\hline & Right & $9(6,7 \%)$ & $11(6,6 \%)$ & \\
\hline & Left & $17(12,7 \%)$ & $13(7,8 \%)$ & \\
\hline \multirow[t]{2}{*}{ Onodi Cells } & Absent & $65(48,5 \%)$ & $77(46,4 \%)$ & \multirow[t]{2}{*}{0,714} \\
\hline & Present & $69(51,5 \%)$ & $89(53,6 \%)$ & \\
\hline
\end{tabular}




\section{DISCUSSION}

$\mathrm{CT}$ is defined as the gold standard in evaluating anatomic variations in paranasal sinuses also with preoperative anatomical evaluations, pathologies and bone integrity as it supplies adequate spatial resolution and generated data can be used for computer-assisted endoscopic sinus surgery (23-25). On the other hand, it is generally known that $\mathrm{CT}$ is liable for the majority of the medical radiation doses in the populations of modern societies. Recently, the use of CBCT in the evaluation of paranasal sinus anatomy has been studied and published (26-29), СBCT generates three-dimensional data on the maxillofacial area, and is progressively being used in numerous dental speciaities as well as otorhinolaryngology. Although CT is important and primary choice for evaluating the paranasal sinuses, CBCT may definitely take on the same role in the planning of endoscopic surgery of the paranasal sinuses, making it possible to obtain high-resolution axial, coronal, and sagittal sections (26). Considering above mentioned arguments, we evaluated CBCT images for analyzing anatomic variations of paranasal sinuses.

Wormold (30) suggested that agger nasi cells are the key to figure out the anatomy of frontal recess at paranasal sinus area. In this study, the prevalence of agger nasi cells was $52,6 \%$. The prevalence of agger nasi cells is remarkably variable, ranging in different studies. Sagar et al (31) has found the prevalence in $94 \%$ of their cases respectively. Han et al (32) reviewed 202 CT scans and found that the agger nasi cells were present in $94,1 \%$ of Chinese patients. On the other hand, Talaiepour et al (33) evaluated 143 patients and agger nasi cells were found in $56,7 \%$ of the cases. Also; there are some other studies lower percentages in their respective studies (34-36). Angélico et al (37) stated that the reason for the discrepancy found in results, was the technique used for evaluation. They reported that researchers used only the CT scan with thicker axial and coronal slices larger than $3 \mathrm{~mm}$ and found lower agger nasi cell percentages. The sagittal reconstructions, with thinner slices provided better examination of nasal structures and expanded the point of view in the understanding of the complex anatomy, allowing to evaluate the extent of structures of paranasal sinuses. In $\mathrm{CBCT}$ systems, image data can be usually demonstrated on a monitor simultaneously showing a segmented 'volume rendered' image as the fourth window in addition to axial, coronal and sagittal planes, which makes the evaluation of paranasal sinuses easy (38).

One of the most common variations of the sinonasal region is pneumatization of the concha - concha bullosa. This variation is most frequently seen in the middle concha followed by the superior concha. In this study, the prevalence of concha bullosa middle was $54,7 \%$ while concha bullosa superior was $7,7 \%$ with no concha bullosa inferior. Turna et al (39) has found that the most prevalent pneumatized concha was the middle concha (57.2\%) with the least prevalent inferior concha by $1 \%$. Aramani et al (40) reviewed 54 CT scans and found that the concha bullosa were present in $53.7 \%$ patients. In our study, the prevalence of concha bullosa was consistent with these studies.

In 1756, infraorbital ethmoid cells were first presented by Albrecht Von Haller and were named as "haller cells". On the other hand the nomenclature for these cells has been replaced with infraorbital ethmoid cells, as they originate from the anterior ethmoid cells and are located in the medial orbital floor (19). The prevelence of infraorbital ethmoid cells presented in different studies includes a wide content between $5,5 \%$ and $45,9 \%$ (41). Fadda et al (42) found the incidence of infraorbital ethmoid cells as $22,8 \%$ on CT scans. Gocmen et al (43) reviewed 300 СВCT scans and from the 300 scans, $2,7 \%$ were showed infraorbital ethmoid cell on the right, 9,3\% on the left and 7,3\% bilaterally. In our study, while in $84,7 \%$ of the cases, no infraorbital ethmoid cells were observed, $4,7 \%$ of the cases were on the right side, $5,7 \%$ were on the left side and $5 \%$ were bilateral. The results of our study are in agreement with these studies.

Although conventional radiographic examinations are used frequently and as the first step examination in practical application, they do not allow for the obvious imaging of ethmoid and sphenoid sinuses. When these are compared by $\mathrm{CT}$, rates of pseudo positive and pseudo negative findings are known to be very high (44). The reported prevalence of the onodi cell is higher in clinic-anatomic studies (42\%-60\%) than the radiologic ones ( $8 \%-24 \%)$. This discrepancy may relate to the angle of computed tomography acquisition or the complexity of imaging interpretation (45). In $47,3 \%$ of our cases, no onodi cells were observed while in $52.7 \%$ of the cases onodi cells were present compatible with the study presented by Senturk et al (46).

\section{CONCLUSION}

The findings of this study point out that CBCT can be used in the analysis of paranasal sinuses. The current study attempted to search numerous paranasal sinus variations and their prevelence. Such morphometric data may provide vital information to otolaryngologists and dental surgeons in preoperative analysis of surgeries associated with paranasal area and may facilitate accurate identification of the anatomy of the paranasal sinus region.

Conflict of Interest: No conflict of interest was declared by the authors.

Financial Disclosure: The authors declared that they did not receive financial support for this study.

\section{REFERENCES}

[1] de Oliveira AG, dos Santos Silveira O, Francio LA, de Andrade Marigo Grandinetti H, Manzi FR. Surg. Radiol. Anat. 2013; 35: 535-8.

[2] Mendiratta V, Baisakhiya N, Singh D, Datta G, Mittal A, Mendiratta P. Sinonasal Anatomical Variants: CT and Endoscopy Study and Its Correlation with Extent of Disease. Indian J Otolaryngol Head Neck Surg. 2016; 68: 352-8. 
[3] Huang BY, Lloyd KM, DelGaudio JM, Jablonowski E, Hudgins PA. Failed endoscopic sinus surgery: spectrum of CT findings in the frontal recess. Radiographics 2009; 29: 177-195.

[4] Musy PY, Kountakis SE. Anatomic findings in patients undergoing revision endoscopic sinus surgery. Am. J. Otolaryngo. 2004; 25: 418-422.

[5] Khalil HS, Eweiss AZ, Clifton N. Radiological findings in patients undergoing revision endoscopic sinus surgery: a retrospective case series study. BMC Ear Nose Throat Disord. 2011;7:11:4.

[6] Wani AA, Kanotra S, Lateef M, Ahmad R, Qazi SM, Ahmad S. CT scan evaluation of the anatomical variations of the ostiomeatal complex. Indian J Otolaryngol Head Neck Surg. 2009; 61: 163 8.

[7] Zinreich SJ, Kennedy DW, Rosenbaum AE, Gayler BW, Kumar AJ, Stammberger $\mathrm{H}$. Paranasal sinuses: $\mathrm{CT}$ imaging requirements for endoscopic surgery. Radiology. 1987; 163: 769-75.

[8] Namdar Pekiner F. Anatomic Variations of Paranasal Sinus on Multidetector Computed Tomography Examinations for Functional Endoscopic Sinus Surgery. MÜSBED 2013; 3: 102106.

[9] Leunig A, Sommer B, Betz CS, Sommer F. Surgical anatomy of the frontal recess-is there a benefit in multiplanar CTreconstruction? Rhinology 2008; 46: 188-194.

[10] Sillers MJ, Kuhn FA, Vickery CL. Radiation exposure in paranasal sinus imaging. Otolaryngol Head Neck Surg. 1995; 112:248251.

[11] Bent JP, Cuilty-Siller C, Kuhn FA. The frontal cell as a cause of frontal sinus obstruction. Am. J. Rhinol. 1994; 8: 185-191.

[12] Kew J, Rees G, Close D, Sdralis T, Sebben, R, Wormald PJ. Multiplanar reconstructed CT images improves depiction and understanding of the anatomy of the frontal sinus and recess. Am. J. Rhinol. 2002; 16:119-123.

[13] Lee WT, Kuhn FA, Citardi MJ. 3D computed tomographic analysis of frontal recess anatomy in patients without frontal sinusitis. Otolaryngol Head Neck Surg. 2004; 131:164-173.

[14] Donizeth-Rodrigues C, Fonseca-Da Silveira M, Gonçalves-De Alencar AH, Garcia-Santos-Silva MA, Francisco-De-Mendonça E, Estrela C. Three-dimensional images contribute to the diagnosis of mucous retention cyst in maxillary sinus. Med. Oral Patol. Oral Cir. Bucal. 2013; 18:e151-157.

[15] Rege IC, Sousa TO, Leles CR, Mendonça EF. Occurrence of maxillary sinus abnormalities detected by cone beam $\mathrm{CT}$ in asymptomatic patients. BMC Oral Health 2012; 10; 12:30.

[16] Park SS, Yoon BN, Cho KS, Roh HJ. Pneumatization pattern of the frontal recess: relationship of the anterior-to-posterior length of frontal isthmus and/or frontal recess with the volume of agger nasi cell. Clin. Exp Otorhinolaryngol. 2010; 3:76-83.

[17] Arslan H, Aydinlioğlu A, Bozkurt M, Egeli E. Anatomic variations of the paranasal sinuses: CT examination for endoscopic sinus surgery. Auris Nasus Larynx. 1999; 26: 39-48.

[18] Kantarci M, Karasen RM, Alper F, Onbas O, Okur A, Karaman A. Remarkable anatomic variations in paranasal sinus region and their clinical importance. Eur J Radiol. 2004; 50: 296-302.

[19] Pekiner FM, Borahan MO, Dumlu A, Özbayrak S. Infraorbital ethmoid (Haller) cells: A Cone-beam computed tomographic study. Oral Radiol. 2014; 30: 219-225.

[20] Basic N, Basic V, Jukic T, Basic M, Jelic M, Hat J. Computed tomographic imaging to determine the frequency of anatomical variations in pneumatization of the ethmoid bone. Eur. Arch. Otorhinolaryngol. 1999; 256: 69-71.
[21] Luxenberger W, Anderhuber W, Stammberger H. Mucocele in an orbitoethmoidal (Haller's) cell (accidentally combined with acute contralateral dacryocystitis). Rhinology. 1999; 37: 37-9.

[22] Chmielik LP, Chmielik A. The prevalence of the onodi cell Most suitable method of CT evaluation in its detection. Int J Pediatr Otorhinolaryngol. 2017; 97: 202-205.

[23] Kandukuri R, Phatak S. Evaluation of sinonasal diseases by computed tomography. J Clin Diagn Res. 2016;10:TC09-TC12.

[24] Kew J, Rees G, Close D, Sdralis T, Sebben, R, Wormald PJ. Multiplanar reconstructed CT images improves depiction and understanding of the anatomy of the frontal sinus and recess. Am J Rhinol. 2002; 16: 119-23.

[25] Coates MH, Whyte AM, Earwaker JW. Frontal recess air cells: spectrum of CT appearances. Australas Radiol. 2003; 47: 4-10.

[26] Al Abduwani J, ZilinSkiene L, Colley S, Ahmed S. Cone beam CT paranasal sinuses versus standard multidetector and low dose multidetector CT studies. Am J Otolaryngol. 2016; 37: 59-64.

[27] Rafferty MA, Siewerdsen JH, Chan Y, Moseley DJ, Daly MJ, Jaffray DA, Irish JC.. Investigation of C-Arm Cone-Beam CT-guided surgery of the frontal recess. Laryngoscope. 2005;115:2138-43.

[28] Zoumalan RA, Lebowitz RA, Wang E, Yung K, Babb JS, Jacobs JB. Flat panel cone beam computed tomography of the sinuses. Otolaryngol Head Neck Surg. 2009; 140: 841-4.

[29] Güldner C, Ningo A, Voigt J, Diogo I, Heinrichs J, Weber R, Wilhelm T, Fiebich

[30] M. Potential of dosage reduction in cone-beam-computed tomography (CBCT) for radiological diagnostics of the paranasal sinuses.Eur Arch Otorhinolaryngol. 2013; 270: 1307-15.

[31] Wormald PJ, Chan SZX. Surgical techniques for the removal of frontal recess cells obstructing the frontal ostium. Am J Rhinol 2003; 17: 221-226.

[32] Sagar GR, Jha BC, Meghanadh KR. A study of anatomy of frontal recess in patients suffering from 'chronic frontal sinus disease'. Indian J Otolaryngol Head Neck Surg 2013; 65: 435-439.

[33] Han D, Zhang L, Ge W, Tao J, Xian J, Zhou B. Multiplanar computed tomographic analysis of the frontal recess region in Chinese subjects without frontal sinus disease symptoms. ORL J Otorhinolaryngol Relat Spec. 2008; 70: 104-12.

[34] Talaiepour AR, Sazgar AA, Bagheri A. Anatomic variations of the paranasal sinuses on CT scan Images. J Dent of Tehran Unv MS. 2005; 2: 142-46

[35] Chaiyasate S, Baron I, Clement P. Analysis of paranasal sinus development and anatomical variations: a CT genetic study in twins. Clin Otolaryngol. 2007; 32: 93-7.

[36] Kayalioglu G, Oyar O, Govsa F. Nasal cavity and paranasal sinus bony variations: a computed tomographic study. Rhinology. 2000; 38: 108-13.

[37] Badia L, Lund VJ, Wei W, Ho WK. Ethnic variation in sinonasal anatomy on CT-scanning. Rhinology. 2005; 43: 210-4.

[38] Angélico Jr FV, Rapoport PB. Analysis of the Agger nasi cell and frontal sinus ostium sizes using computed tomography of the paranasal sinuses. Braz J Otorhinolaryngol. 2013; 79: 285-92.

[39] Horner K, Jacobs R, Schulze R. Dental CBCT equipment and performance issues. Radiat Prot Dosimetry 2013; 153: 212218.

[40] Turna, Ö, Aybar MD, Karagöz, Y, Tuzcu, G. Anatomic variations of the paranasal sinus region: Evaluation with multidetector CT. İstanbul Med J. 2014; 15: 104-9. 
[41] Aramani A, Karadi RN, Kumar S. A. Study of anatomical variations of osteomeatal complex in chronic rhinosinusitis patients-CT findings. J Clin Diagn Res. 2014; 8: KC01-4.

[42] Caversaccio M. Boschung U. Mudry A. Anat. 2011; 193: 185190.

[43] Fadda GLRosso, S, Aversa S, Petrelli A, Ondolo C, Succo G. Multiparametric statistical correlations between paranasal sinus anatomic variations and chronic rhinosinusitis. Acta Otorhinolaryngol Ital 2012; 32: 244-25.

[44] Göçmen G, Borahan MO, Aktop S, Dumlu A, Pekiner FN, Göker K. Effect of septal deviation, concha bullosa and Haller's cell on maxillary sinus's inferior pneumatization; a retrospective study. Open Dent J. 2015; 31: 282-6.

[45] Turkdogan FT, Turkdogan KA, Dogan M, Atalar MH. Assessment of sphenoid sinus related anatomic variations with computed tomography. Pan Afr Med J. 2017; 13;27: 109.

[46] Meybodi AT, Vigo V, Benet A. The Onodi Cell: An Anatomic illustration. World Neurosurg. 2017;103: 950.e5-950.e6.

[47] Senturk M, Guler I, Azgin I, Sakarya EU, Ovet G, Alatas N, Tolu I, Erdur O. The role of Onodi cells in sphenoiditis: results of multiplanar reconstruction of computed tomography scanning. Braz J Otorhinolaryngol. 2017; 83: 88-93.

How to cite this article: Turan N., Ozdemir A. G., Kaya H., Bilgili F., Hasmaden E., Akkus Y., Lutfiye T. M., Tirank M. Physical Self Perception, Body Posture of Nursing Students and Associated Factors. Clin Exp Health Sci 2019; DOI: 10.5152/clinexphealthsci.2018.1001 